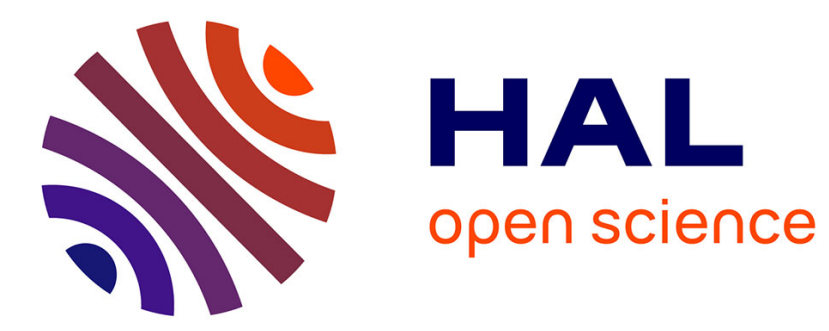

\title{
Polymeric microstructures with shape-memory properties for biomedical use built by stereolithography
}

Shahriar Sharifi, Sébastien Blanquer, Dirk Grijpma

\section{To cite this version:}

Shahriar Sharifi, Sébastien Blanquer, Dirk Grijpma. Polymeric microstructures with shape-memory properties for biomedical use built by stereolithography. Journal of Applied Biomaterials \& Functional Materials, 2012, 10 (3), pp.280 - 286. 10.5301/JABFM.2012.10367 . hal-01833148

\author{
HAL Id: hal-01833148 \\ https://hal.science/hal-01833148
}

Submitted on 10 Dec 2020

HAL is a multi-disciplinary open access archive for the deposit and dissemination of scientific research documents, whether they are published or not. The documents may come from teaching and research institutions in France or abroad, or from public or private research centers.
L'archive ouverte pluridisciplinaire HAL, est destinée au dépôt et à la diffusion de documents scientifiques de niveau recherche, publiés ou non, émanant des établissements d'enseignement et de recherche français ou étrangers, des laboratoires publics ou privés. 


\title{
Polymeric microstructures with shape-memory properties for biomedical use built by stereolithography
}

\author{
Shahriar Sharifi', Sebastien Blanquer ${ }^{2}$, Dirk W. Grijpma ${ }^{1,2}$ \\ 'Department of Biomedical Engineering, University Medical Centre Groningen and University of Groningen, Groningen - \\ The Netherlands \\ ${ }^{2}$ Department of Biomaterials Science and Technology, University of Twente, Enschede - The Netherlands
}

\begin{abstract}
Purpose: The aim of this study was to design and build porous microstructures with shape memory behaviour using biodegradable poly(D,L-lactide-co-trimethylene carbonate) dimethacrylate macromers. These microstructures could be advantageous for tissue engineering and other advanced biomedical applications.

Methods: Porous structures with a gyroid pore network architecture showing average pore sizes of $930 \mu \mathrm{m}$ and complete pore interconnectivity were prepared by stereolithography. Built structures were characterized by micro-computed tomography $(\mu-\mathrm{CT})$. Shape recovery and shape fixity of microstructures after $40 \%$ and $70 \%$ compression were evaluated.

Results: At $37^{\circ} \mathrm{C}$ the flexible structures showed compression modulus values of $60 \mathrm{KPa}$ and could be fully compressed. Thermal analysis showed that the built networks were amorphous with $\mathrm{Tg}$ values of $23{ }^{\circ} \mathrm{C}$. After compression to 40 and $70 \%$, shape fixity and shape recovery of the structures at respectively $0{ }^{\circ} \mathrm{C}$ and $37^{\circ} \mathrm{C}$ was almost quantitative.

Conclusions: The well-defined pore network characteristics and the shape-memory properties of these structures allow their use as deployable tissue engineering scaffolds.
\end{abstract}

Key words: Biodegradable, Poly(D,L-lactide-co-trimethylene carbonate) networks, Shape-memory properties, Stereolithography

Accepted: October 25, 2012

\section{INTRODUCTION}

Building microstructures from shape-memory polymers could be advantageous for tissue engineering and other advanced biomedical applications. These porous materials display a unique combination of high surface area, high compressibility and shape-memory behavior that gives them a wide range of potential biomedical applications (1-3). These structures can be implanted in a compact form via minimally invasive surgeries and deployed to reach complex final shapes. For example, collapsible shape-memory tissue engineering scaffolds seeded with cells can potentially be implanted in a minimally invasive manner to initiate the repair or reconstruction of tissues or organs (4). Deployable shape-memory cellular structures can also be employed to allow cellular ingrowth or blood coagulation in an aneurysm sac to facilitate occlusion of the aneurysm (5).

Scientific literature on the preparation of microstructures from shape-memory polymers is scarce. The microstructures that have been described are mainly cellular solids based on epoxies or urethanes that have been obtained by conventional foaming processes, such as pro- cesses involving chemical blowing agents, gas foaming or particulate leaching $(1,6-8)$. Although making 3-dimensional foams with good shape-memory properties is possible using these techniques, there is poor control over the architecture of the pore network and the pore interconnectivity.

Porosity, pore size and pore interconnectivity along with bioactivity and physical-mechanical properties of the matrix are the main design parameters when biomedical applications of these implants are considered. For example as tissue engineering scaffolds, the porosity of scaffolds plays a main role in determining oxygen and nutrient transport to the cells. Besides that, cell differentiation, ingrowth and integration with neighboring tissue are also strongly influenced by the porosity and microarchitecture of the scaffold $(9,10)$.

Fabrication of microstructures by solid freeform fabrication techniques, such as stereolithography (SLA), allows the production of structures with well-defined pore network architectures (11). In this study, porous structures showing shape memory behavior were precisely prepared by SLA using biocompatible and biodegradable poly $(D, L-$ lactide-co-trimethylene carbonate) (P(DLLA-CO-TMC)) 
dimethacrylate macromers. These copolymers and their networks have been used for a number of biomedical applications including tissue engineering (12-14). The structures obtained were characterized by thermal, mechanical and structural analyses, and their shape fixity and recoverability were evaluated as well. The biocompatibility of the prepared structures was evaluated by direct contact cell cultures using human adipose stem cells.

\section{MATERIALS AND METHODS}

\section{Materials}

Trimethylene carbonate (1,3-dioxan-2-one; TMC) was obtained from Boehringer Ingelheim, Germany. $D, L-$ Lactide (DLLA) was obtained from Purac Biochem, The Netherlands. Stannous octoate (tin 2-ethylhexanoate; SnOct $\left.{ }_{2}\right), 1,6$-hexanediol (99\%), triethyl amine (TEA), pentaerythritol triacrylate, anhydrous dichloromethane and methacrylic anhydride (MAA) were obtained from SigmaAldrich, USA. The reagents and solvents were of analytical grade and used as received.

Synthesis and characterization of P(DLLA-CO-TMC) oligomers and macromers

$\mathrm{P}$ (DLLA-CO-TMC) oligomer with a targeted number average molecular weight $\left(\mathrm{M}_{\mathrm{n}}\right)$ of $30 \mathrm{~kg} \cdot \mathrm{mol}^{-1}$ and a TMC/ DLLA molar ratio of 0.4:0.6 was synthesized by ring-opening polymerization of the corresponding monomers using 1,6-hexanediol as an initiator and SnOct, as a catalyst. TMC, DLLA and SnOct $2\left(2 \times 10^{-4}\right.$ mole per mole of monomer) along with the initiator, were charged into a 3-necked round bottom flask, and the reaction was continued for 3 days at $130^{\circ} \mathrm{C}$ under nitrogen. Macromers were prepared by reacting the terminal hydroxyl groups of the hydroxyl group terminated $\mathrm{P}(\mathrm{DLLA}-\mathrm{CO}-\mathrm{TMC})$ oligomers with MAA in the presence of TEA. The required amounts of the oligomers, MAA and TEA were measured out in 1:4:4 molar ratios and charged into a 3-necked flask. The reaction was allowed to proceed for 7 days at room temperature. The $\mathrm{P}$ (DLLA-CO-TMC) dimethacrylate formed was then purified by precipitation in a cold excess of diethyl ether and stored at $-20{ }^{\circ} \mathrm{C}$ until used.

The monomer conversions, molecular weights $\left(M_{n}\right)$ and degrees of functionalization were determined by high-resolution proton nuclear magnetic resonance spectroscopy ('H-NMR; Varian Innova $300 \mathrm{MHz}$, USA) using $\mathrm{CDCl}_{3}$ as a solvent (Merck, Germany).

The thermal properties of the oligomers and macromers were evaluated by differential scanning calorimetry (DSC) using a PerkinElmer Pyris DSC apparatus. Samples weighing $5-10 \mathrm{mg}$ were heated to $100^{\circ} \mathrm{C}$ at a rate of $10^{\circ} \mathrm{C} / \mathrm{min}$, and then cooled to $-50^{\circ} \mathrm{C}$ at rate of $5{ }^{\circ} \mathrm{C} / \mathrm{min}$.
After 5 minutes at this temperature, a second scan was recorded from $-50{ }^{\circ} \mathrm{C}$ to $100{ }^{\circ} \mathrm{C}$ at $10{ }^{\circ} \mathrm{C} / \mathrm{min}$. The glass transition temperature of the specimens, $\mathrm{T}_{g^{\prime}}$ was determined as the midpoint of the change in the heat capacity.

Formulation of stereolithography resins and building of shape-memory structures

To prepare resin formulations for SLA, P(DLLA-COTMC) macromers were mixed with $50 \mathrm{wt} \%$ propylene carbonate as a nonreactive diluent (15). To this mixture, $5 \mathrm{wt} \%$ Lucirin TPO-L, $0.15 \mathrm{wt} \%$ Orasol Orange G and 5 $\mathrm{wt} \%$ pentaerythritol triacrylate were added as photoinitiator, dye and cross-linking agent, respectively. Cylindrical 3-dimensional porous structures with a gyroid pore network architecture with an average pore size of 1,000 $\mu \mathrm{m}$ and a porosity of $70 \%$, were designed using K3dSurf v0.6.2 (freeware from http://k3dsurf.sourceforge.net) and Rhinoceros 3D (McNeel, Europe) computer software. These structures were then built from the abovementioned resins by SLA using an EnvisionTec Perfactory Mini Multilens (Germany) SLA apparatus.

To precisely control the depth of cure in building the constructs, SLA working curves were first prepared to assess the curing behavior of the resin. Three-dimensional microstructure networks were then prepared in the SLA apparatus by photo-cross-linking subsequent layers of resin with thicknesses of $25 \mu \mathrm{m}$, upon which a pixel pattern is projected. Each layer was illuminated at an intensity of approximately $1,000 \mathrm{~mW} / \mathrm{dm}^{2}$ for 30 seconds. After building, the structures were extracted for 72 hours with a 1:1 mixture of ethanol and water to leach out propylene carbonate. The final structures were obtained after 2 days drying at $40^{\circ} \mathrm{C}$.

\section{Characterization of built porous structures}

The gel contents of the porous structures built were determined by conducting swelling studies using dichloromethane as a swelling agent. The extracted samples were weighed and immersed in excess dichloromethane for 48 hours. Then the swollen specimens were dried in a vacuum oven at $40{ }^{\circ} \mathrm{C}$ until constant weight, and weighed again. From these values the gel fraction was determined (16).

The thermal properties of the structures built were determined by DSC, using a similar method to that used for the oligomers and macromers. Elastic moduli of the structures were determined by compressive testing using a Zwick Z020 (Germany) tensile tester. Compression tests were carried out at room temperature, physiological temperature $\left(37^{\circ} \mathrm{C}\right)$ and at $0{ }^{\circ} \mathrm{C}$ at a crosshead speed of $50 \mathrm{~mm} /$ $\min$.

Values of the onset strain of densification were determined by plotting the energy efficiency parameter as a function of the compressive strain (17). The efficiency 
parameter is defined as the ratio of the absorbed energy up to strain $(\varepsilon)$ divided by the stress itself:

$$
\mathrm{E}=\frac{\int_{0}^{c} \sigma(\varepsilon) d(\varepsilon)}{\sigma(\varepsilon)}
$$

The onset strain of densification was determined as the strain at which the energy efficiency reaches a maximum value.

Micro-computed tomography ( $\mu$-CT) (GE eXplore Locus SP $\mu$-CT scanner with a spatial resolution of $7 \mu \mathrm{m}$ ) was employed to visualize the porous structures built by SLA. Scanning was done applying an X-ray tube voltage of $80 \mathrm{kV}$, a current of $80 \mu A$ and an exposure time of 3,000 milliseconds. No filter was applied. After reconstruction using the Feldkamp algorithm, thresholded isosurface images were obtained (GE MicroView software). Porosities, pore size distributions and average pore sizes of the structures prepared by SLA were assessed from the $\mu$-CT data.

\section{Shape-memory properties}

Cylindrical scaffolds with gyroid pore network architectures (diameter $12 \mathrm{~mm}$, height $14 \mathrm{~mm}$ ) were immersed in a basin of water of $37{ }^{\circ} \mathrm{C}$ and compressed into a temporary shape ( $40 \%$ and $70 \%$ compression) at $10 \%$ per minute. Fixing of the shape was done by decreasing the temperature to $0{ }^{\circ} \mathrm{C}$ while maintaining the compressive strain. To ensure uniform heating, the specimens were kept at the test temperature for 10 minutes. To evaluate shape recovery, the sample with the fixed temporary shape was again immersed in water at $37^{\circ} \mathrm{C}$ until the specimen returned to its permanent shape. Quantitative shape-memory properties were evaluated using a digital camera to record the changes in shape of the specimens.

The shape fixity $\left(R_{f}\right)$ and the shape recovery $\left(R_{f}\right)$ were calculated using the following formulas:

$$
\begin{gathered}
R_{f}(\%)=\frac{l_{u}}{l_{i}} \times 100 \\
R_{r}(\%)=\frac{l_{p}-l_{r}}{l_{p}} \times 100
\end{gathered}
$$

In Equation 2, $l_{i}$ and $l_{u}$, respectively, represent the height of samples after compression (to $40 \%$ or $70 \%$ ) and cooling, and the height of the cooled and compressed samples after unloading. In Equation 3, $l_{r}$ represents the recovered height of the sample after warming up to $37^{\circ} \mathrm{C}$, while $l_{p}$ represents the original height of sample at room temperature. These experiments were repeated using 3 samples. The porosities, pore size distributions and aver- age pore sizes of the structures in their temporary shape (at $40 \%$ and $70 \%$ compression) and after their shape recovery were evaluated by $\mu$-CT as described in a previous section.

\section{Biocompatibility}

The biocompatibility of the porous structures built was assessed using adipose stem cell culturing in direct contact with the surface of the materials. First, the scaffolds were sterilized by immersing in ethanol $70 \%$ for $30 \mathrm{~min}$ utes, followed by several washing steps with sterile phosphate-buffered saline (PBS). Human adipose stem cells (passage 7) were seeded into and onto the built porous $\mathrm{P}(\mathrm{DLLA}-\mathrm{CO}-\mathrm{TMC})$ structures in wells of cell-adherent polystyrene tissue culture plates at a concentration of $2.5 \times 10^{5}$ cells per scaffold. After 3 hours of preincubation, the wells were filled with $3 \mathrm{~mL}$ medium and incubated for 2 weeks, replenishing the medium every 2 days. Cell viability was evaluated using a methylene blue assay. Briefly, the medium was aspirated from the wells, and the scaffolds were washed once in PBS. Then, the scaffolds were incubated in $10 \%$ paraformaldehyde fixative solution (Sigma Aldrich, USA) for 20 minutes and washed with PBS. An amount of $100 \mu \mathrm{L}$ of methylene blue solution was dropped onto the scaffolds; after 3 minutes they were washed several times with PBS until no blue staining came out of the scaffold. The stained cell-seeded cell-containing scaffolds were then visualized by optical microscopy.

\section{RESULTS}

Synthesis and characterization of P(DLLA-CO-TMC) oligomers and macromers

Using hexanediol as a bifunctional initiator, a mixture of $D, L$-lactide and TMC was polymerized by ring opening polymerization to yield telechelic oligomeric diols. The number average molecular weight of the oligomers determined by ${ }^{1} \mathrm{H}-\mathrm{NMR}$ was $28 \times 10^{3} \mathrm{~g} \cdot \mathrm{mol}^{-1}$. The TMC/DLLA molar ratio in the oligomers calculated from the ratio of the integral values of $\mathrm{CH}_{2} \mathrm{OCOO}$ of TMC at 4.08-4.39 ppm and of $-\mathrm{CHCOO}$ of lactide at 1.42-1.85 ppm was found to be $58.3: 41.7$. End functionalization of the oligomers to form P(DLLA-CO-TMC) dimethacrylate was confirmed by the appearance of protons of vinyl groups at 5.6 and 6.2 ppm and of the methylene protons of the methacrylate groups at $1.95 \mathrm{ppm}$ in the ${ }^{1} \mathrm{H}-\mathrm{NMR}$ spectra. The degree of functionalization (DF) of macromers was determined from the peak areas corresponding to the methacrylate protons (5.6 and $6.2 \mathrm{ppm}$ ) and the hexanediol $-\mathrm{CH}_{2} \mathrm{O}$ - protons (1.2 ppm). A DF of $70 \%$ was obtained for the macromers.

DSC analysis showed that the oligomers and the mac- 


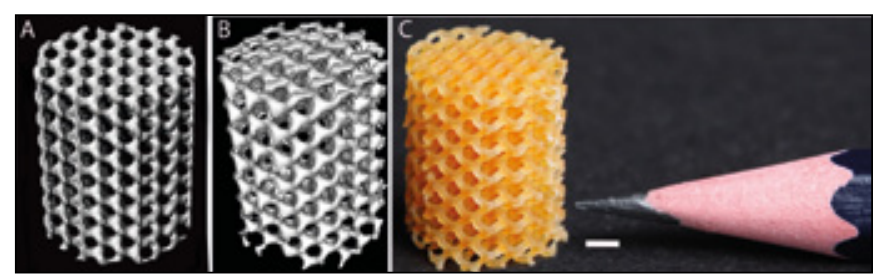

Fig. 1 - Porous structures designed with gyroid pore network architecture and made by stereolithography (SLA) using P(DLLA-co-TMC) dimethacrylate-based resins. A) Computer-aided design of the porous structure. B) Micro-computed tomography image of the structure. C) Photographic image of the structure after extraction. Scale bar is equal to $2.5 \mathrm{~mm}$.

romers were completely amorphous, they showed $T_{\mathrm{g}}$ values of $13.0^{\circ} \mathrm{C}$ and $13.2{ }^{\circ} \mathrm{C}$, respectively.

\section{Preparation of porous structures and their characterization}

The porous structures with gyroid pore network architecture made from shape-memory macromers by SLA were characterized by analysis of their microarchitecture, mechanical testing and swelling studies. First $\mu$-CT was employed to assess the porosity and the pore network characteristics of the scaffolds built. Figure 1 shows computer-aided designs (CADs) of the porous structures with gyroid pore network architectures and the corresponding $\mu$-CT images of the structures built. As can be seen in the figure, the structure was accurately built as it very closely resembles the design. The porosity of the architecture was $70 \%$ with an average pore size of $1,000 \mu \mathrm{m}$. According to the $\mu-C T$ data, the structures built had a porosity of $70.9 \%$ and an average pore size of $931 \mu \mathrm{m}$. The pore network is fully interconnected.

Water ethanol mixtures which are used for the extraction of the propylene carbonate diluent are poor solvents for the unreacted macromers. The unreacted macromer was extracted from the built structures with dichloromethane, which is a good solvent for the $\mathrm{P}$ (DLLA-co-TMC) macromers. The scaffolds built were found to have high gel contents of $88 \%$ as determined in swelling experiments. According to DSC, the network structures were amorphous with $T_{\mathrm{g}}$ values of 23 ${ }^{\circ} \mathrm{C}$. These values were somewhat higher than those of the macromers and oligomers, as could be expected.

Figure 2 shows the compression stress-strain curves of the structures built, at $0{ }^{\circ} \mathrm{C}$, at room temperature and at physiological temperatures of $37^{\circ} \mathrm{C}$. As also is the case with foamed materials, the 3 stages of deformation: bending, buckling and densification are evident in this figure, especially regarding the porous specimen compressed at room temperature. At this temperature, the onset of densification can be determined to be approximately $46 \%$ compression; at 37

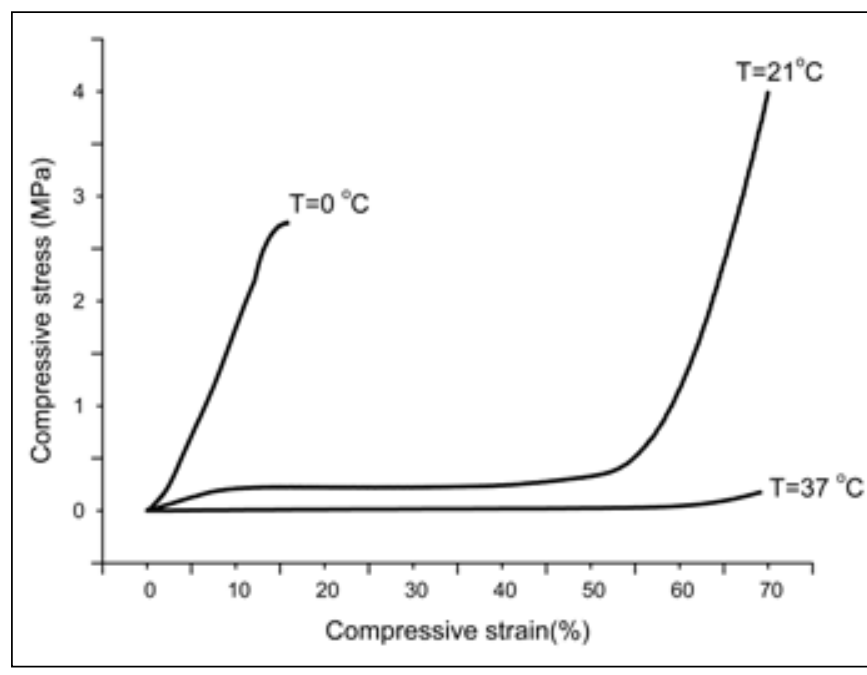

Fig. 2 - Compression behavior of $70 \%$ porous structures designed with gyroid pore network architecture and prepared from P(DLLA-Co-TMC) macromers at different temperatures. The networks had a glass transition temperature of $23^{\circ} \mathrm{C}$.

${ }^{\circ} \mathrm{C}$ the onset of densification is at approximately $55 \%$ compression.

In agreement with the thermal analysis, the $70 \%$ porous scaffolds exhibited typical rubbery behavior at room temperature and at $37^{\circ} \mathrm{C}$, with elastic modulus values of $2,540 \mathrm{kPa}$ and $60.4 \mathrm{kPa}$, respectively. These structures prepared from $\mathrm{P}$ (DLLA-co-TMC) dimethacrylate-based resins were more rigid glassy materials at $0{ }^{\circ} \mathrm{C}$ and had an elasticity modulus of $20,900 \mathrm{kPa}$.

\section{Shape-memory properties}

In Table I the results of the shape fixity and shape recovery of the prepared porous structures after compression to $40 \%$ and $70 \%$ at $37{ }^{\circ} \mathrm{C}$ are presented. Also the corresponding average pore sizes are given.

Upon unloading, after being compressed to $40 \%$ and $70 \%$, the prepared porous structures did not show spontaneous shape recovery at $0{ }^{\circ} \mathrm{C}$. This indicates excellent shape fixity of the materials. For both compression levels, a high value of recovery was observed at $37{ }^{\circ} \mathrm{C}$; however, the rates of shape recovery for specimens compressed to $40 \%$ were lower than those for specimens compressed to $70 \%$ (data not shown).

In Figure 3, images of the porous structures with gyroid pore network are shown in their original (permanent) shape and in their temporary, compressed state. Also indicated is the pore size distribution of the pores in the corresponding states as determined by $\mu$-CT. Upon increasing the temperature from $0^{\circ} \mathrm{C}$ to $37^{\circ} \mathrm{C}$, the $\mathrm{P}(\mathrm{DLLA}-\mathrm{CO}-\mathrm{TMC})$ structure deployed from its temporary shape to its original permanent dimensions and shape. In the uncompressed original state, pores 

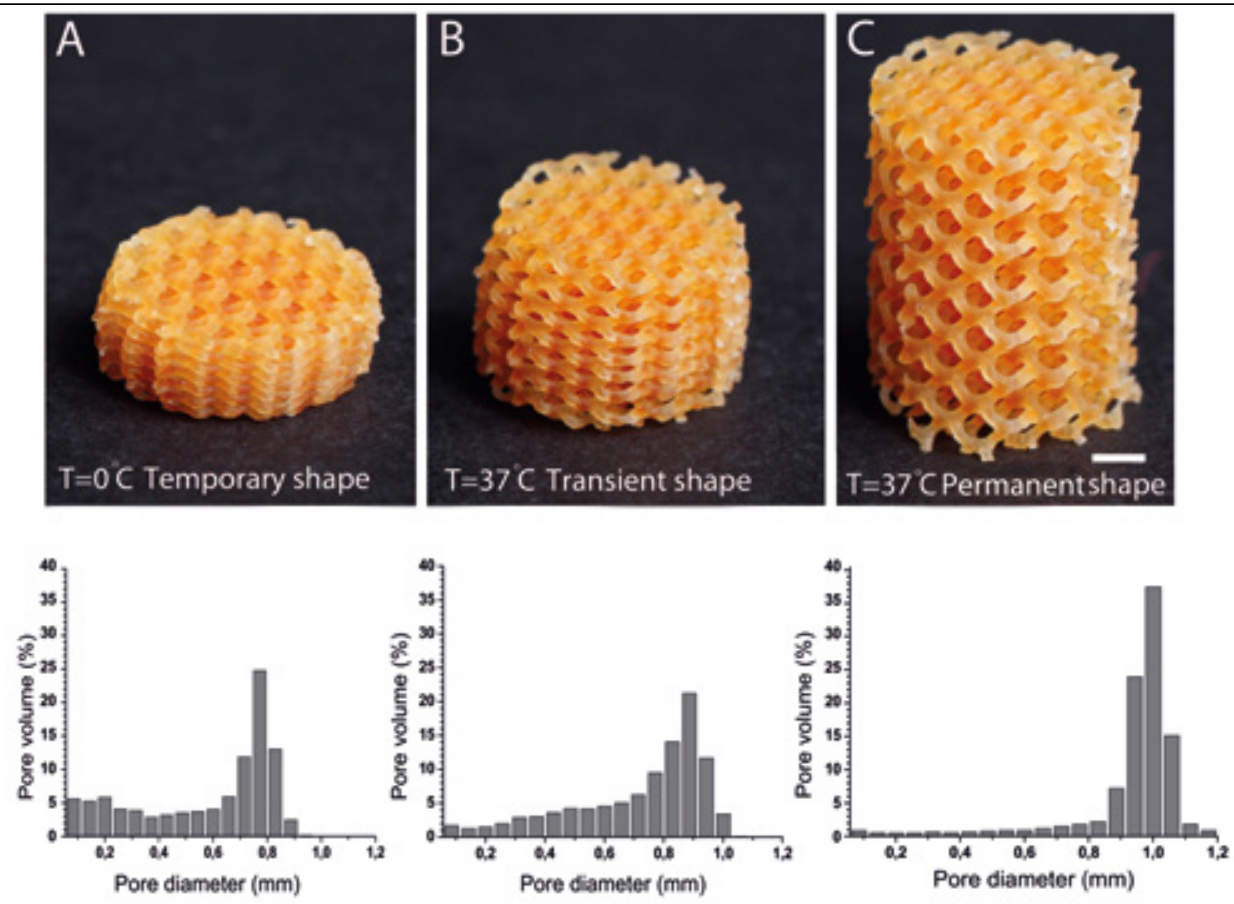

TABLE I - SHAPE FIXITY $\left(R_{\mathrm{f}}\right)$ AND SHAPE RECOVERY $\left(\mathrm{R}_{\mathrm{r}}\right)$ OF PREPARED POROUS STRUCTURES AFTER 40\% AND 70\% COMPRESSION AT $37^{\circ} \mathrm{C}$

\begin{tabular}{cccc}
\hline Compression (\%) & $\begin{array}{c}\mathbf{R}_{\mathbf{f}} \\
(\%)\end{array}$ & $\begin{array}{c}\mathbf{R}_{\mathbf{r}} \\
(\%)\end{array}$ & $\begin{array}{c}\text { Average pore } \\
\text { size }^{*}(\boldsymbol{\mu m})\end{array}$ \\
\hline 0 & -- & -- & 931 \\
40 & $99 \pm 1$ & $95 \pm 1.3$ & 718 \\
70 & $99 \pm 2$ & $98 \pm 1.1$ & 577 \\
\hline
\end{tabular}

Shape fixity and shape recovery were determined at $0^{\circ} \mathrm{C}$ and $37^{\circ} \mathrm{C}$, respectively. Data are presented as means \pm standard deviation. The corresponding average pore sizes in the temporary state at $0{ }^{\circ} \mathrm{C}$ are presented as well.

* Single determinations.

in the porous structures ranging in size from 886 to $1,172 \mu \mathrm{m}$ made up more than $86 \%$ of the pore volume. Upon being compressed to $40 \%$ and $70 \%$, the (average) pore sizes of the structures can be seen to decrease significantly.

The proliferation of adipose stem cells seeded into and onto the scaffolds is shown in Figure 4. The images correspond to cell culturing periods of 1 day and 7 days.

\section{DISCUSSION}

Photo-cross-linkable P(DLLA-co-TMC) macromers can be conveniently prepared by ring-opening polymerization of TMC and $D, L$-lactide initiated by hexane diol and subsequent functionalization in a reaction with methacrylic anhydride. Depending on the monomer composition, $\operatorname{poly}(D, L$-lactide-Co-trimethylene carbonate)s can

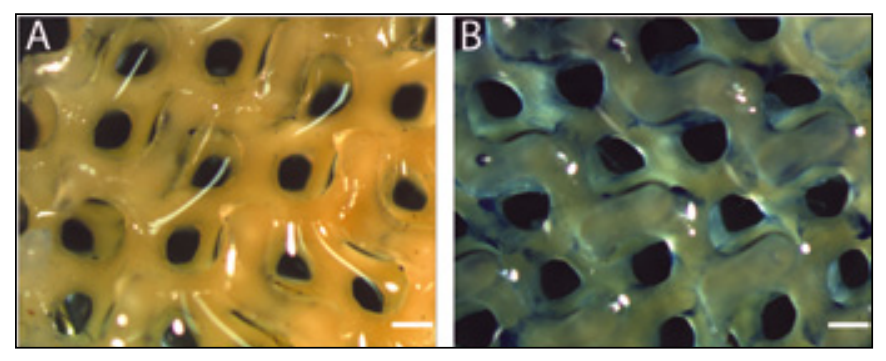

Fig. 4 - Optical microscopy images of methylene blue-stained adipose stem cells seeded into and onto the $P(D L L A-C O-T M C)$ scaffolds prepared by stereolithography. Images were taken after 1 day (A) and after 7 days (B) of cell culturing (scale bar $=1 \mathrm{~mm}$ ).

have widely differing glass transition temperatures, elastic moduli, tensile strengths and degradation. This makes these tailorable materials suitable for a variety of biomedical applications (18). In this work we employed P(DLLACO-TMC) network materials with a DLLA to TMC molar ratio of 0.6:0.4, because this polymer is amorphous with a glass transition (after photo-cross-linking of the macromers) at close to room temperatures. In addition, the macromers with relatively high molecular weights of 30 kg. $\mathrm{mol}^{-1}$ were used for photo-crosslinking. We found in preliminary work (data not shown) that increasing the molecular weight of the macromers resulted in significant improvement of the mechanical properties (strength, resilience and toughness) of the networks formed. This makes these networks especially attractive for use in preparing minimally invasive surgically implantable medical devices and tissue engineering scaffolds. Such devices could be implanted in a temporary shape below $T_{\mathrm{g}}$ that, after 
implantation and warming up to body temperature, would expand to their permanent shape to perform a specific desired function.

With SLA, it was possible to prepare complex structures from these $\mathrm{P}$ (DLLA-CO-TMC) macromers that possess shape-memory properties. As an example of a complex device, a cylindrical porous structure with a gyroid pore network architecture was built. The gyroid pore network has an infinitely connected triply periodic minimal surface with a large specific surface area and high pore interconnectivity. These architectures could therefore be of great interest for tissue engineering scaffolds or other volume-filling applications (19).

As our results confirm, the SLA technique allowed for the precisely controlled preparation of structures with designed (and desired) pore characteristics. The results provide information regarding the shape fixity and shape recovery of the structures built. Excellent shape fixity and near complete recovery of the specimens can be expected from the large difference in elasticity moduli of the specimens below and above the glass transition temperature, as illustrated in Figure 2.

Porous polymeric shape-memory materials are usually prepared by foaming techniques using supercritical carbon dioxide or gas-blowing methods. These foams usually have very broad pore size distributions (1). Since the gyroid pore network architecture is a designed structure that contains fully connected regular channels throughout the structure, the pore size distribution is quite low (Figs. 3 and 4).

In microporous structures prepared from shape-memory polymers, the number, size and location of struts and walls between the pores play an important role in determining the compressibility and the shape recovery after deformation of the structures. During the deformation process, the porous structure deforms by bending of the cell walls (closed-cell foams) or cell edges (open-cell foams) (20). Figure 2 shows the strain-stress curves of the P(DLLA$\mathrm{CO}-\mathrm{TMC}$ ) structures. When the network is in the glassy state at $0{ }^{\circ} \mathrm{C}$, the structure deforms elastically in a uniform way. At room temperature, which is close to $\mathrm{T}_{\text {o }}$ of the network, the specimen first uniformly deforms elastically until a stress plateau is reached. At this point, $\mu$-CT results in Figure 3 show that there is a significant decrease in pore size. Figure 2 shows that at $37{ }^{\circ} \mathrm{C}$ after approximately $50 \%$ $60 \%$ compression, densification can be observed. Here, the compressive stress increases significantly with the applied strain, due to contacting of the cell walls. This onset of densification is in correspondence with the previously calculated value of $55 \%$ compression. Because the gyroid pore network consists of many regular struts with no clear boundaries between the pores, collapse of the pore network due to compression occurs elastically, and complete shape recovery is still possible even after $70 \%$ compression, which is well above the onset of densification.
The cell culture study using adipose stem cells clearly demonstrates the biocompatibility of the built structures. The very open architecture can be advantageous in tissue engineering, specifically when large tissues are to be engineered, as the diffusion of nutrients and oxygen to the cells will not be hampered.

\section{CONCLUSIONS}

Porous structures were prepared by SLA using P(DLLAco-TMC) macromers containing $40 \mathrm{~mol} \%$ TMC. Porous structures with high interconnectivity were obtained. These structures showed good shape-memory properties in terms of shape fixity at low temperatures and excellent recovery upon heating to $40{ }^{\circ} \mathrm{C}$. Structures did not show any adverse cytotoxicity when cultured with human adipose stem cells. The results here indicate the feasibility of making complex structures with shape-memory properties to fulfil several needs in the biomedical field.

Financial support: This research forms part of the Project P2.01 IDiDAS of the research program of the BioMedical Materials Institute, cofunded by the Dutch Ministry of Economic Affairs, Agriculture and Innovation. The financial contribution of the Dutch Arthritis Foundation is gratefully acknowledged.

Conflict of interest: The authors declare no conflict of interest.

Address for correspondence:

Dirk W. Grijpma

Department of Biomedical Engineering

University Medical Center Groningen

A. Deusinglaan 1, building 3215, FB40

9713 AV Groningen, The Netherlands

d.w.grijpma@med.umcg.nl

\section{REFERENCES}

1. Madbouly SA, Kratz K, Klein F, Lutzow K, Lendlein A. Thermomechanical behaviour of biodegradable shape-memory polymer foams. Mater Res Soc Symp P. 2009;1190:99-104.

2. Metcalfe A, Desfaits AC, Salazkin I, Yahia L, Sokolowski WM, Raymond J. Cold hibernated elastic memory foams for endovascular interventions. Biomaterials. 2003;24: 491497.

3. De Nardo L, Alberti R, Cigada A, Yahia L, Tanzi MC, Fare S. Shape memory polymer foams for cerebral aneurysm repa- 
ration: effects of plasma sterilization on physical properties and cytocompatibility. Acta Biomater. 2009;5:1508-1518.

4. Neuss S, Blomenkamp I, Stainforth R, et al. The use of a shape-memory poly(e-caprolactone)dimethacrylate network as a tissue engineering scaffold. Biomaterials. 2009;30:1697-1705.

5. Maitland DJ, Small W, Ortega JM, et al. Prototype laseractivated shape memory polymer foam device for embolic treatment of aneurysms. J Biomed Opt. 2007;12:030504

6. Di Prima MA, Lesniewski M, Gall K, McDowell DL, Sanderson T, Campbell D. Thermo-mechanical behavior of epoxy shape memory polymer foams. Smart Mater Struct. 2007; 16:2330-2340.

7. De Nardo L, Bertoldi S, Tanzi MC, Haugen HJ, Fare S. Shape memory polymer cellular solid design for medical applications. Smart Mater Struct. 2011;20: 035004.

8. Kim BK. Shape memory effects of molded flexible polyurethane foam. Smart Mater Struct. 2007;16:2486-2491.

9. Altomare L, Fare S. Cells response to topographic and chemical micropatterns. J Appl Biomater Biomech. 2008;6:132-143.

10. Melchels FP, Tonnarelli B, Olivares AL, et al. The influence of the scaffold design on the distribution of adhering cells after perfusion cell seeding. Biomaterials. 2011;32:28782884

11. Melchels FP, Bertoldi K, Gabbrielli R, Velders AH, Feijen J, Grijpma DW. Mathematically defined tissue engineering scaffold architectures prepared by stereolithography. Biomaterials. 2010;31:6909-6916.

12. Pego AP, Siebum B, Van Luyn MJA, et al. Preparation of degradable porous structures based on 1,3-trimethylene carbonate and D,L-lactide (co)polymers for heart tissue engineering. Tissue Eng. 2003;9:981-994.
13. Dargaville BL, Vaquette $\mathrm{C}$, Peng $\mathrm{H}$, et al. Cross-linked poly(trimethylene carbonate-Co-L-lactide) as a biodegradable, elastomeric scaffold for vascular engineering applications. Biomacromolecules. 2011;12:3856-3869.

14. Bat E, van Kooten TG, Feijen J, Grijpma DW. Crosslinking of trimethylene carbonate and D,L-lactide (CO-) polymers by gamma irradiation in the presence of pentaerythritol triacrylate. Macromol Biosci. 2011;11:952-961.

15. Schuller-Ravoo S, Feijen J, Grijpma DW. Preparation of flexible and elastic poly(trimethylene carbonate) structures by stereolithography. Macromol Biosci. 2011;11:1662-1671.

16. Sharifi S, Mirzadeh H, Imani M, et al. Synthesis, photocrosslinking characteristics, and biocompatibility evaluation of $\mathrm{N}$-vinyl pyrrolidone/polycaprolactone fumarate biomaterials using a new proton scavenger. Polym Advan Technol. 2008;19:1828-1838.

17. Avalle M, Belingardi G, Montanini R. Characterization of polymeric structural foams under compressive impact loading by means of energy-absorption diagram. Int J Impact Eng. 2001;25:455-472.

18. Pego AP, Poot AA, Grijpma DW, Feijen J. Physical properties of high molecular weight 1,3-trimethylene carbonate and D,L-lactide copolymers. J Mater Sci Mater M. 2003;14:767-773.

19. Jansen J, Melchels FPW, Grijpma DW, Feijen J. Fumaric acid monoethyl ester-functionalized poly(D,L-lactide)/Nvinyl-2-pyrrolidone resins for the preparation of tissue engineering scaffolds by stereolithography. Biomacromolecules. 2008; 10:214-220.

20. Vaz MF, Fortes MA. Characterization of deformation bands in the compression of cellular materials. J Mater Sci Lett. 1993;12:1408-1410. 
Copyright of Journal of Applied Biomaterials \& Functional Materials is the property of Wichtig Editore and its content may not be copied or emailed to multiple sites or posted to a listserv without the copyright holder's express written permission. However, users may print, download, or email articles for individual use. 